\title{
Fe-Mediated Nitrogen Fixation with a Metallocene Mediator: Exploring pKa Effects and Demonstrating Electrocatalysis
}

Matthew J. Chalkley, Trevor J. Del Castillo, Benjamin D. Matson, and Jonas C. Peters

J. Am. Chem. Soc., Just Accepted Manuscript • DOI: 10.1021/jacs.8b02335 • Publication Date (Web): 18 Apr 2018

Downloaded from http://pubs.acs.org on April 18, 2018

\section{Just Accepted}

"Just Accepted" manuscripts have been peer-reviewed and accepted for publication. They are posted online prior to technical editing, formatting for publication and author proofing. The American Chemical Society provides "Just Accepted" as a service to the research community to expedite the dissemination of scientific material as soon as possible after acceptance. "Just Accepted" manuscripts appear in full in PDF format accompanied by an HTML abstract. "Just Accepted" manuscripts have been fully peer reviewed, but should not be considered the official version of record. They are citable by the Digital Object Identifier (DOI®). "Just Accepted" is an optional service offered to authors. Therefore, the "Just Accepted" Web site may not include all articles that will be published in the journal. After a manuscript is technically edited and formatted, it will be removed from the "Just Accepted" Web site and published as an ASAP article. Note that technical editing may introduce minor changes to the manuscript text and/or graphics which could affect content, and all legal disclaimers and ethical guidelines that apply to the journal pertain. ACS cannot be held responsible for errors or consequences arising from the use of information contained in these "Just Accepted" manuscripts. 


\section{INTRODUCTION}

There has been substantial recent progress in the development of soluble, well-defined molecular catalysts for $\mathrm{N}_{2}$-to$\mathrm{NH}_{3}$ conversion, commonly referred to as the nitrogen reduction reaction $\left(\mathrm{N}_{2} \mathrm{RR}\right) .{ }^{1}$ Nevertheless, a significant and unmet challenge is to develop molecular catalysts, and conditions, compatible with electrocatalytic $\mathrm{N}_{2} \mathrm{RR}$. Progress in this area could have both fundamental and practical benefits, including access to informative in situ mechanistic studies via electrochemical techniques, and an electrochemical means to translate solar or otherwise derived chemical currency $\left(\mathrm{H}^{+} / \mathrm{e}^{-}\right)$into $\mathrm{NH}_{3}$. The latter goal, which has been the subject of numerous studies using heterogeneous catalysts, is key to the long-term delivery of new ammonia synthesis technologies for fertilizer and/or fuel. ${ }^{2}$

Many soluble coordination complexes are now known that electrocatalytically mediate the hydrogen evolution reaction (HER), ${ }^{3}$ the carbon dioxide reduction reaction $\left(\mathrm{CO}_{2} \mathrm{RR}\right),{ }^{4}$ and the oxygen reduction reaction $\left(\mathrm{O}_{2} \mathrm{RR}\right) .{ }^{5}$ The study of such systems has matured at a rapid pace in recent years, coinciding with expanded research efforts towards solar-derived fuel systems. In this context, it is noteworthy how little corresponding progress has been made towards the discovery of soluble molecular catalysts that mediate electrocatalytic $\mathrm{N}_{2} \mathrm{RR}$. To our knowledge, only two prior systems address this topic directly. $6,7,8$

More than three decades ago, Pickett and coworkers reported that a Chatt-type tungsten-hydrazido(2-) complex could be electrochemically reduced to release ammonia (and trace hydrazine), along with some amount of a reduced tungsten-dinitrogen product; the latter species serves as the source of the tungsten-hydrazido(2-) complex (via its protonation by acid) ${ }^{6 a}$ By cycling through such a process, an electrochemical, but not an electrocatalytic, synthesis of ammonia was demonstrated. Indeed, efforts to demonstrate electrocatalysis with this and related systems instead led to substoichiometric $\mathrm{NH}_{3}$ yields. ${ }^{6 c}$

An obvious limitation to progress in electrochemical $\mathrm{N}_{2} \mathrm{RR}$ by molecular systems concerns the small number of synthetic $\mathrm{N}_{2} \mathrm{RR}$ catalysts that have been available for study; it is only in the past five years that sufficiently robust catalyst systems have been identified to motivate such studies. In addition, the conditions that have to date been employed to mediate $\mathrm{N}_{2} \mathrm{RR}$ have typically included non-polar solvents, such as heptane, toluene, and diethyl ether $\left(\mathrm{Et}_{2} \mathrm{O}\right)$, that are not particularly well-suited to electrochemical studies owing to the lack of compatible electrolytes. ${ }^{1}$

Nevertheless, several recent developments, including ones from our lab, point to the likelihood that iron (and perhaps other) molecular coordination complexes may be able to mediate electrocatalytic $\mathrm{N}_{2} \mathrm{RR}$ in organic solvent. Specifically, our lab recently reported that a tris(phosphine)borane iron complex, $\mathrm{P}_{3}{ }^{\mathrm{B}} \mathrm{Fe}^{+}$, that is competent for catalytic $\mathrm{N}_{2} \mathrm{RR}$ with chemical reductants, can also mediate electrolytic $\mathrm{N}_{2}$-to$\mathrm{NH}_{3}$ conversion, ${ }^{6 \mathrm{~d}}$ with the available data (including that presented in this study) pointing to bona fide electrocatalysis in $\mathrm{Et}_{2} \mathrm{O}$.

Focusing on the $\mathrm{P}_{3}{ }^{\mathrm{B}} \mathrm{Fe}^{+}$catalytic $\mathrm{N}_{2} \mathrm{RR}$ system, a development germane to the present study was its recently discovered compatibility with reagents milder than those that had been originally employed. ${ }^{\text {lc }}$ Thus, decamethylcobaltocene $\left(\mathrm{Cp}{ }_{2} \mathrm{Co}\right)$ and diphenylammonium acid are effective for $\mathrm{N}_{2} \mathrm{RR}$ 
catalysis; these reagents give rise to fast, and also quite selective (> 70\% vs HER), $\mathrm{N}_{2} \mathrm{RR}$ catalysis at low temperature and pressure in ethereal solvent. In addition, based on preliminary spectroscopic evidence and density functional theory (DFT) predictions, it appears that a protonated metallocene species, $\mathrm{Cp} *\left(\eta^{4}-\mathrm{C}_{5} \mathrm{Me}_{5} \mathrm{H}\right) \mathrm{Co}^{+}$, may be an important intermediate of $\mathrm{N}_{2} \mathrm{RR}$ catalysis under such conditions. Indeed, we have suggested that $\mathrm{Cp}^{*}\left(\eta^{4}-\mathrm{C}_{5} \mathrm{Me}_{5} \mathrm{H}\right) \mathrm{Co}^{+}$may serve as a proton-coupled-electron-transfer $(\mathrm{PCET})$ donor $\left(\mathrm{BDE}_{\mathrm{C}-\mathrm{H}}(\mathrm{calc})=31 \mathrm{kcal}\right.$ $\left.\mathrm{mol}^{-1}\right)$, thereby mediating net $\mathrm{H}$-atom transfers to generate $\mathrm{N}-$ $\mathrm{H}$ bonds during $\mathrm{N}_{2} \mathrm{RR}^{9}{ }^{9}$ The presence of a metallocene mediator might, we therefore reasoned, enhance $\mathrm{N}_{2} \mathrm{RR}$ during electrocatalysis.

We present here a study of the effect of $\mathrm{p} K_{\mathrm{a}}$ on the selectivity of $\mathrm{P}_{3}{ }^{\mathrm{B}} \mathrm{Fe}^{+}$for $\mathrm{N}_{2} \mathrm{RR}$ vs HER. By using substituted anilinium acids, we are able to vary the acid $\mathrm{p} K_{\mathrm{a}}$ over 9 orders of magnitude and find that the selectivity is highly correlated with the $\mathrm{p} K_{\mathrm{a}}$. In our efforts to investigate the origin of the observed $\mathrm{p} K_{\mathrm{a}}$ effect, we found, to our surprise, that in stoichiometric reactions, the catalytically competent anilinium triflate acids are unable to faciltate productive $\mathrm{N}-\mathrm{H}$ bond formation with early-stage $\mathrm{N}_{2}$-fixation intermediates. We therefore hypothesize that the formation of a protonated metallocene species, $\mathrm{Cp}^{*}\left(\eta^{4}-\mathrm{C}_{5} \mathrm{Me}_{5} \mathrm{H}\right) \mathrm{Co}^{+}$, plays a critical role in $\mathrm{N}-\mathrm{H}$ bondforming reactions, either via PCET, PT, or a combination of both during $\mathrm{N}_{2} \mathrm{RR}$ catalysis. DFT studies support this hypothesis and also establish that the observed $\mathrm{p} K_{\mathrm{a}}$ correlation with $\mathrm{N}_{2} \mathrm{RR}$ selectivity can be explained by the varying ability of the acids to protonate $\mathrm{Cp}^{*}{ }_{2} \mathrm{Co}$. The suggested role of this protonated metallocene intermediate in $\mathrm{N}-\mathrm{H}$ bond forming reactions led us to test the effect of $\mathrm{Cp}^{*}{ }_{2} \mathrm{Co}^{+}$as an additive in the electrolytic synthesis of $\mathrm{NH}_{3}$ mediated by $\mathrm{P}_{3}{ }^{\mathrm{B}} \mathrm{Fe}^{+}$. We find that the addition of co-catalytic $\mathrm{Cp}_{2}{ }_{2} \mathrm{Co}^{+}$enhances the yield of $\mathrm{NH}_{3}$ without decreasing the Faradaic efficiency (FE), and furnishes what is to our knowledge the first unambiguous demonstration of electrocatalytic $\mathrm{N}_{2} \mathrm{RR}$ mediated by a soluble, molecular coordination complex.

\section{RESULTS AND DISCUSSION}

\section{$\mathrm{p} K_{\mathrm{a}}$ studies.}

In our recent study on the ability of $\mathrm{P}_{3}{ }^{\mathrm{B}} \mathrm{Fe}^{+}$to perform $\mathrm{N}_{2} \mathrm{RR}$ with $\mathrm{Cp}^{*}{ }_{2} \mathrm{Co}$ as the chemical reductant, ${ }^{9}$ we found that there was a marked difference in efficiency for $\mathrm{NH}_{3}$ generation with diphenylammonium triflate $\left(\left[\mathrm{Ph}_{2} \mathrm{NH}_{2}\right][\mathrm{OTf}]\right)$ versus anilinium triflate $\left(\left[\mathrm{PhNH}_{3}\right][\mathrm{OTf}]\right)$. In that study, we posited that this difference could arise from several possibilities, including the differential solubility, sterics, or $\mathrm{p} K_{\mathrm{a}}$ 's of these acids. ${ }^{9}$

To investigate the last possibility, we have studied the efficiency of the catalysis by quantifying the $\mathrm{NH}_{3}$ and $\mathrm{H}_{2}$ produced when using substituted anilinium acids with different $\mathrm{p} K_{\mathrm{a}}$ values (Table 1 ). The table is organized in increasing acid strength, from [ $\left.{ }^{4-\mathrm{OMe}} \mathrm{PhNH}_{3}\right][\mathrm{OTf}]$ as the weakest acid to the perchlorinated derivative ([ $\left.\left.{ }^{\mathrm{per}-\mathrm{Cl}} \mathrm{PhNH}_{3}\right][\mathrm{OTf}]\right)$ as the strongest. Importantly, good total electron yields $(85.8 \pm 3.3)$ were obtained in all cases. As can be seen from the table, the $\mathrm{NH}_{3}$ efficiencies are found to be strongly correlated with $\mathrm{p} K_{\mathrm{a}}{ }^{10}$

In particular, a comparison of the efficiency for $\mathrm{NH}_{3}$ with the $\mathrm{p} K_{\mathrm{a}}$ of the anilinium acid used gives rise to four distinct activity regimes (Table 1, Figure 1). One regime that is completely inactive for $\mathrm{N}_{2} \mathrm{RR}$, but active for HER, is defined by the weakest acid, $\left[{ }^{4-\mathrm{OMe}} \mathrm{PhNH}_{3}\right][\mathrm{OTf}]\left(\mathrm{p} K_{\mathrm{a}}=8.8\right) .{ }^{11}$ A gradual increase in observed $\mathrm{NH}_{3}$ yields, coupled with a decrease in $\mathrm{H}_{2}$ yield, comprises a second regime, in which the acid is strengthened from $\left[\mathrm{PhNH}_{3}\right][\mathrm{OTf}]\left(\mathrm{p} K_{\mathrm{a}}=7.8\right)$, to $\left[{ }^{2,6-}\right.$ $\left.{ }^{\mathrm{Me}} \mathrm{PhNH}_{3}\right][\mathrm{OTf}]\left(\mathrm{p} K_{\mathrm{a}}=6.8\right)$, to $\left[{ }^{2-\mathrm{Cl}} \mathrm{PhNH}_{3}\right][\mathrm{OTf}]\left(\mathrm{p} K_{\mathrm{a}}=5.6\right)$.

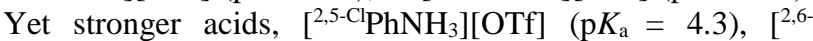
$\left.{ }^{\mathrm{Cl}} \mathrm{PhNH}_{3}\right][\mathrm{OTf}]\left(\mathrm{p} K_{\mathrm{a}}=3.4\right)$, and $\left.{ }^{2,4,6-\mathrm{Cl}} \mathrm{PhNH}_{3}\right][\mathrm{OTf}]\left(\mathrm{p} K_{\mathrm{a}}=\right.$ 2.1 ), constitute another, most active $\mathrm{N}_{2} \mathrm{RR}$ regime, one in which the $\mathrm{H}_{2}$ yields are nearly invariant. ${ }^{12}$ The highest selectivity for $\mathrm{N}_{2} \mathrm{RR}(\sim 78 \%)$ was observed using [2,5$\left.{ }^{\mathrm{Cl}} \mathrm{PhNH}_{3}\right][\mathrm{OTf}]$ as the acid. A final regime of very low $\mathrm{N}_{2} \mathrm{RR}$ activity is encountered with $\left[{ }^{\text {per-Cl}} \mathrm{PhNH}_{3}\right][\mathrm{OTf}]\left(\mathrm{p} K_{\mathrm{a}}=1.3\right)$ as the acid. We suspect this last acid undergoes unproductive
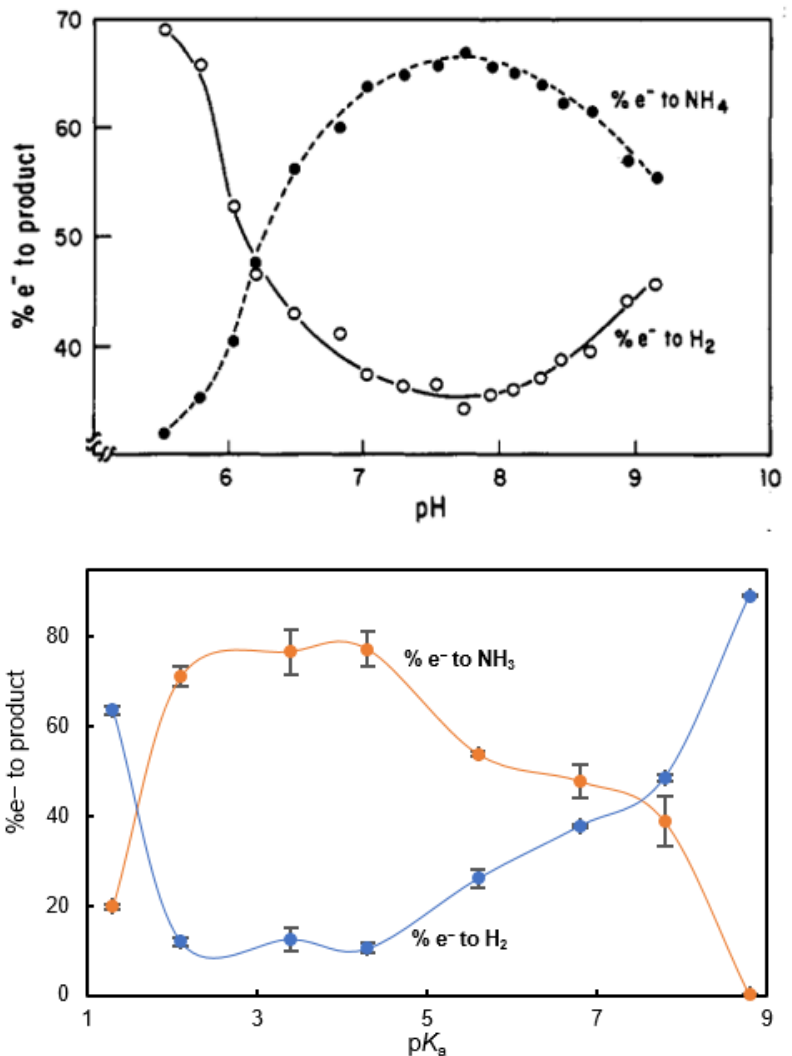

Figure 1. (top) Percentage of electrons being used to form $\mathrm{NH}_{3}$ or $\mathrm{H}_{2}$ at different $\mathrm{pH}$ values by the FeMo-nitrogenase in A. vinelandii. Reprinted with permission from Pham, D. N.; Burgess, B. K. Biochemistry 1993, 32, 13725. Copyright 1993 American Chemical Society. (bottom) Percentage of electrons being used to form $\mathrm{NH}_{3}$ or $\mathrm{H}_{2}$ at different $\mathrm{p} K_{\mathrm{a}}$ values by $\mathrm{P}_{3}{ }^{\mathrm{B}} \mathrm{Fe}^{+}$.

Table 1. Literature and calculated $\mathrm{pK}_{\mathrm{a}}$ values and efficiencies observed in catalytic $\mathrm{N}_{2}$-to- $\mathrm{NH}_{3}$ conversion

\begin{tabular}{|c|c|c|c|c|c|c|c|}
\hline & $\begin{array}{c}\mathrm{p} K_{\mathrm{a}}^{\exp } \\
(\mathrm{THF})^{10}\end{array}$ & $\begin{array}{c}\mathrm{p} K_{\mathrm{a}}^{\text {calc }} \\
(298 \mathrm{~K})^{a}\end{array}$ & $\begin{array}{c}\mathrm{p} K_{\mathrm{d}}^{\text {calc }} \\
(195 \mathrm{~K})^{b}\end{array}$ & $\begin{array}{l}\text { Equiv of } \\
\mathrm{NH}_{3} / \mathrm{Fe}\end{array}$ & $\begin{array}{c}\% \text { yield of } \\
\mathrm{NH}_{3} / \mathrm{e}^{-}\end{array}$ & $\begin{array}{c}\% \text { yield of } \\
\mathrm{H}_{2} / \mathrm{e}^{-c}\end{array}$ & $\begin{array}{c}\text { Total } \\
\text { Yield/e }\end{array}$ \\
\hline$\left[{ }^{4-\mathrm{OMe}} \mathrm{PhNH}_{3}\right][\mathrm{OTf}]$ & 8.8 & 9.6 & 15.7 & $0.04 \pm 0.01$ & $0.2 \pm 0.1$ & $89.1 \pm 0.2$ & 89.3 \\
\hline$\left[\mathrm{PhNH}_{3}\right][\mathrm{OTf}]$ & 7.8 & 7.7 & 13.8 & $7.3 \pm 0.1$ & $40.4 \pm 0.5$ & $48.6 \pm 0.7$ & 87.5 \\
\hline$\left[{ }^{2,6-\mathrm{Me}} \mathrm{PhNH}_{3}\right][\mathrm{OTf}]$ & 6.8 & 7.3 & 13.2 & $8.6 \pm 0.7$ & $47.5 \pm 4.0$ & $37.8 \pm 0.2$ & 85.6 \\
\hline$\left[\mathrm{Cp} *\left(\right.\right.$ exo $\left.\left.-\eta^{4}-\mathrm{C}_{5} \mathrm{Me}_{5} \mathrm{H}\right) \mathrm{Co}\right][\mathrm{OTf}]$ & N/A & 9.2 & 11.8 & - & - & - & - \\
\hline
\end{tabular}




\begin{tabular}{|c|c|c|c|c|c|c|c|}
\hline$\left[{ }^{2-\mathrm{Cl}} \mathrm{PhNH}_{3}\right][\mathrm{OTf}]$ & 5.6 & 5.6 & 6.0 & $10.7 \pm 0.1$ & $53.9 \pm 0.4$ & $26.1 \pm 1.9$ & 80.0 \\
\hline$\left[{ }^{2,5-\mathrm{Cl}} \mathrm{PhNH}_{3}\right][\mathrm{OTf}]$ & 4.3 & 4.0 & 5.0 & $13.9 \pm 0.7$ & $77.5 \pm 3.8$ & $10.5 \pm 1.1$ & 87.7 \\
\hline$\left[{ }^{2,6-\mathrm{Cl}} \mathrm{PhNH}_{3}\right][\mathrm{OTf}]$ & 3.4 & 3.4 & 3.4 & $13.8 \pm 0.9$ & $76.7 \pm 4.9$ & $12.6 \pm 2.5$ & 89.3 \\
\hline$\left[2,4,6-\mathrm{Cl} \mathrm{PhNH}_{3}\right][\mathrm{OTf}]$ & 2.1 & 2.7 & 1.8 & $12.8 \pm 0.4$ & $70.9 \pm 2.2$ & $12.0 \pm 0.8$ & 83.1 \\
\hline$\left[{ }^{\text {per-Cl}} \mathrm{PhNH}_{3}\right][\mathrm{OTf}]$ & 1.3 & 0.8 & 0.4 & $3.6 \pm 0.1$ & $19.9 \pm 0.5$ & $63.5 \pm 1.1$ & 83.5 \\
\hline
\end{tabular}

[ $\left.{ }^{4-\mathrm{OMe}_{e}} \mathrm{PhNH}_{3}\right][\mathrm{OTf}]=4$-methoxyanilinium triflate, $\left[\mathrm{PhNH}_{3}\right][\mathrm{OTf}]=$ anilinium triflate, $\left[{ }^{2,6-\mathrm{Me}^{-}} \mathrm{PhNH}_{3}\right][\mathrm{OTf}]=2,6$-dimethylanilinium triflate,

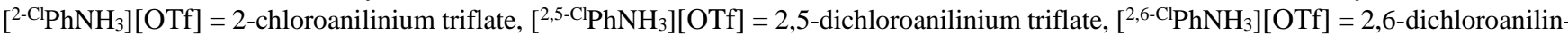

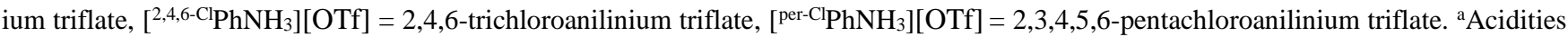
calculated at $298 \mathrm{~K}$ in THF and referenced to the known literature value for $\left[{ }^{2,6-C l} \mathrm{PhNH}_{3}\right][\mathrm{OTf}] .{ }^{\mathrm{b}}$ All species calculated as the ion-paired

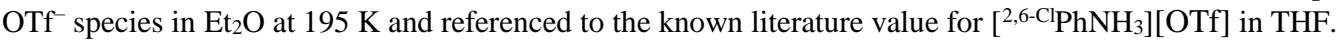

reduction via ET, thereby short-circuiting $\mathrm{N}_{2} \mathrm{RR}$. The only other $\mathrm{N}_{2} \mathrm{RR}$ system for which this type of acid-dependent correlation has been systematically studied is the enzyme MoFenitrogenase. ${ }^{13,14}$ As shown in Figure 1 , the $\mathrm{N}_{2} \mathrm{RR}$ vs HER activity of $\mathrm{P}_{3}{ }^{\mathrm{B}} \mathrm{Fe}^{+}$as a function of acid strength, is, in broad terms, similar to the behavior of the enzyme ${ }^{13}$ across a wide $\mathrm{pH}$ range.

In a previous study of $\mathrm{Cp}^{*}{ }_{2} \mathrm{Co}$-mediated $\mathrm{N}_{2} \mathrm{RR}$ by $\mathrm{P}_{3}{ }^{\mathrm{B}} \mathrm{Fe}^{+},{ }^{9}$ we identified that $\mathrm{P}_{3}{ }^{\mathrm{B}} \mathrm{FeN}_{2}{ }^{-}$forms under the catalytic conditions. Earlier studies on the reactivity of $\mathrm{P}_{3}{ }^{\mathrm{B}} \mathrm{FeN}_{2}{ }^{-}$with an excess of soluble acids, including HOTf and $\left[\mathrm{H}\left(\mathrm{OEt}_{2}\right)_{2}\right]\left[\mathrm{BAr}_{4} \mathrm{~F}_{4}\right]\left(\mathrm{HBAr}_{4}^{\mathrm{F}}, \mathrm{BAr}_{4}{ }_{4}=\right.$ tetrakis(3,5- bis(trifluoromethyl)phenyl)borate)), at $-78^{\circ} \mathrm{C}_{\text {in }} \mathrm{Et}_{2} \mathrm{O}$, established rapid formation of the doubly protonated species, $\mathrm{P}_{3}{ }^{\mathrm{B}} \mathrm{FeNNH}{ }_{2}{ }^{+} .{ }^{15}$ Recent computational work from our group suggests that, under catalytic conditions with a soluble acid, different efficiencies for $\mathrm{N}_{2} \mathrm{RR}$ (versus HER) by $\mathrm{P}_{3}{ }^{\mathrm{E}} \mathrm{Fe}$ catalysts $(\mathrm{E}=\mathrm{B}, \mathrm{C}, \mathrm{Si}$ ) are likely correlated to the rate of formation and consumption of early $\mathrm{N}_{2} \mathrm{RR}$ intermediates (i.e., $\mathrm{P}_{3}{ }^{\mathrm{E}} \mathrm{FeNNH}$ and $\left.\mathrm{P}_{3}{ }^{\mathrm{E}} \mathrm{FeNNH}_{2}{ }^{+/ 0}\right) .{ }^{16}$ Thus, we were interested in the reactivity of these anilinium triflate acids with $\mathrm{P}_{3}{ }^{\mathrm{B}} \mathrm{FeN}_{2}{ }^{-}$, reasoning they may show differential efficiency in the formation of $\mathrm{P}_{3}{ }^{\mathrm{B}} \mathrm{FeNNH}_{2}^{+}$.

To our surprise, a freeze-quench EPR spectrum of the reaction of excess [ ${ }^{2,6-C l} \mathrm{PhNH}_{3}$ ] [OTf] (high $\mathrm{N}_{2} \mathrm{RR}$ efficiency regime) at $-78{ }^{\circ} \mathrm{C}$ in $\mathrm{Et}_{2} \mathrm{O}$ with $\mathrm{P}_{3}{ }^{\mathrm{B}} \mathrm{FeN}_{2}{ }^{-}$does not show any $\mathrm{P}_{3}{ }^{\mathrm{B}} \mathrm{FeNNH}_{2}{ }^{+}$. Also, freeze-quench Mössbauer analysis shows the formation of the oxidized products $\mathrm{P}_{3}{ }^{\mathrm{B}} \mathrm{FeN}_{2}$ and $\mathrm{P}_{3}{ }^{\mathrm{B}} \mathrm{Fe}^{+}$, but nothing assignable to $\mathrm{P}_{3}{ }^{\mathrm{B}} \mathrm{FeNNH}_{2}{ }^{+}$(see SI for relevant spectra). Analysis of such a reaction for $\mathrm{NH}_{3}$ or $\mathrm{N}_{2} \mathrm{H}_{4}$ after warming shows no fixed-N products. The observation of exclusive oxidation, rather than productive $\mathrm{N}-\mathrm{H}$ bond formation, is analogous to what is observed upon addition of 1 equiv of a soluble acid $\left(\mathrm{HBAr}_{4}^{\mathrm{F}}\right.$ or HOTf) to $\mathrm{P}_{3}{ }^{\mathrm{B}} \mathrm{FeN}_{2}{ }^{-}$. We have previously suggested that if unstable $\mathrm{P}_{3}{ }^{\mathrm{B}} \mathrm{FeNNH}$ is formed (eq 1) without excess acid to trap it (to form more stable $\mathrm{P}_{3}{ }^{\mathrm{B}} \mathrm{FeNNH}{ }_{2}^{+}$, eq 2 ), then it can decay bimolecularly with the loss of $1 / 2 \mathrm{H}_{2}$ to form $\mathrm{P}_{3}{ }^{\mathrm{B}} \mathrm{FeN}_{2}$ (eq 3 ).

(1) $\mathrm{P}_{3}{ }^{\mathrm{B}} \mathrm{FeN}_{2}^{-}+\mathrm{H}^{+} \rightarrow \mathrm{P}_{3}{ }^{\mathrm{B}} \mathrm{FeNNH}$

(2) $\mathrm{P}_{3}{ }^{\mathrm{B}} \mathrm{FeNNH}+\mathrm{H}^{+} \rightarrow \mathrm{P}_{3}{ }^{\mathrm{B}} \mathrm{FeNNH}_{2}{ }^{+}$

(3) $\mathrm{P}_{3}{ }^{\mathrm{B}} \mathrm{FeNNH} \rightarrow \mathrm{P}_{3}{ }^{\mathrm{B}} \mathrm{FeN}_{2}+1 / 2 \mathrm{H}_{2}$

The low solubility of the anilinium triflate acids studied herein, in excess (50 equiv) and under the catalytically relevant conditions $\left(1 \mathrm{~mL} \mathrm{Et}_{2} \mathrm{O},-78^{\circ} \mathrm{C}\right)$, likely leads to a similar scenario; consequently, $\mathrm{P}_{3}{ }^{\mathrm{B}} \mathrm{FeNNH}$ that is generated is not efficiently captured by excess acid, leading instead to bimolecular $\mathrm{H}_{2}$ loss. In accord with this idea, a freeze-quench EPR spectrum of the addition of 50 equiv of $\left[{ }^{2,6-C l} \mathrm{PhNH}_{3}\right]\left[\mathrm{BAr}_{4}^{\mathrm{F}}\right]$, a far more ether soluble derivative of the same anilinium, to
$\mathrm{P}_{3}{ }^{\mathrm{B}} \mathrm{FeN}_{2}{ }^{-}$shows $\mathrm{P}_{3}{ }^{\mathrm{B}} \mathrm{FeNNH}{ }_{2}{ }^{+}$formation, and the detection of fixed-N products upon warming $\left(0.20 \pm 0.04\right.$ eq. $\mathrm{NH}_{3}$ per $\left.\mathrm{Fe}\right)$.

These observations must next be reconciled with the seemingly contradictory observation that comparatively efficient $\mathrm{N}_{2} \mathrm{RR}$ catalysis is observed when [ [,6-Cl $\left.\mathrm{PhNH}_{3}\right]$ [OTf], and other anilinium triflate acids, are employed under catalytic conditions. For example, $\left[\mathrm{Ph}_{2} \mathrm{NH}_{2}\right]$ [OTf] leads to better efficiency for $\mathrm{NH}_{3}$ formation versus $\left[\mathrm{Ph}_{2} \mathrm{NH}_{2}\right]\left[\mathrm{BAr}_{4}{ }_{4}\right](72 \pm$ $3 \%$ and $42 \pm 6 \%$, respectively). A key difference between the stoichiometric reactions described above, and the catalytic reaction, is the presence of $\mathrm{Cp}^{*}{ }_{2} \mathrm{Co}$ in the latter.

We have suggested that $\mathrm{Cp} *{ }_{2} \mathrm{Co}$ can be protonated under the catalytic reaction conditions, to form $\mathrm{Cp}^{*}\left(\eta^{4}-\right.$ $\left.\mathrm{C}_{5} \mathrm{Me}_{5} \mathrm{H}\right) \mathrm{Co}^{+},{ }^{9}$ which may then play a role in $\mathrm{N}-\mathrm{H}$ bond forming steps. ${ }^{17}$ The results presented here (and below) suggest that such a mechanism is not only plausible, but is likely necessary, to explain the observed catalytic results with anilinium triflate acids. Given the effect of $\mathrm{p} K_{\mathrm{a}}$ on the efficiency for $\mathrm{N}_{2} \mathrm{RR}$, we now hypothesize that this effect can arise from the relative energetics and rates of $\mathrm{Cp} *{ }_{2} \mathrm{Co}$ protonation by the different anilinium triflate acids.

\section{Computational Studies.}

To investigate the kinetics and thermodynamics of $\mathrm{Cp}{ }_{2} \mathrm{Co}$ protonation by anilinium triflate acids we turned to a computational study. DFT-D ${ }_{3}^{18}$ calculations were undertaken at the TPSS/def2-TZVP(Fe); def2-SVP ${ }^{19}$ level of theory, as used previously for studies of this $\mathrm{P}_{3}{ }^{\mathrm{B}} \mathrm{Fe}^{+}$system. ${ }^{20}$ The free energy of $\mathrm{H}^{+}$exchange $\left(\Delta \mathrm{G}_{\mathrm{a}}\right)$ was calculated for all of the anilinium acids used (representative example shown in eq 4), and also for $\mathrm{Cp}^{*}\left(\right.$ exo- $\left.\eta^{4}-\mathrm{C}_{5} \mathrm{Me}_{5} \mathrm{H}\right) \mathrm{Co}^{+}$, in $\mathrm{Et}_{2} \mathrm{O}$ at $298 \mathrm{~K}$. These free energies were then used to determine the acid $\mathrm{p} K_{\mathrm{a}}$ 's, with inclusion of a term to reference them to the literature $\mathrm{p} K_{\mathrm{a}}$ value

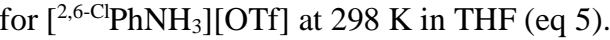

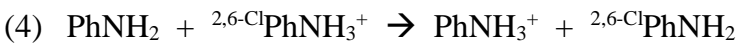

(5) $\mathrm{p} K_{\mathrm{a}}\left(\mathrm{PhNH}_{3}{ }^{+}\right)=-\Delta \mathrm{G}_{\mathrm{a}} /(2.303 \times \mathrm{RT})+\mathrm{p} K_{\mathrm{a}}\left({ }^{2,6-\mathrm{Cl}} \mathrm{PhNH}_{3}{ }^{+}\right)$

Because we presume that variable triflate hydrogen bonding effects $\left(0.5-10 \mathrm{kcal} \mathrm{mol}^{-1}\right)$ are likely to be important under the catalytic conditions (low temperature and low polarity solvent), we additionally calculated the free energy for net HOTf exchange reactions $\left(\Delta \mathrm{G}_{\mathrm{d}}\right)$ at $195 \mathrm{~K}$ in $\mathrm{Et}_{2} \mathrm{O}$ (representative example shown in eq 6 ). The free energies of these reactions can then be used to determine a $\mathrm{p} K_{\mathrm{d}}$, referenced to the $\mathrm{p} K_{\mathrm{a}}$ value for [ $\left.{ }^{2,6-\mathrm{Cl}} \mathrm{PhNH}_{3}\right][\mathrm{OTf}]$ at $298 \mathrm{~K}$ in THF, for ease of comparison (eq 7). Hereafter, we use these $\mathrm{p} K_{\mathrm{d}}$ values for discussion, but note that use of the $\mathrm{p} K_{\mathrm{a}}$ values instead does not substantively alter the conclusions drawn.

(6) $\mathrm{PhNH}_{2}+\left[{ }^{2,6-\mathrm{Cl}} \mathrm{PhNH}_{3}\right][\mathrm{OTf}] \rightarrow$

$\left[\mathrm{PhNH}_{3}\right][\mathrm{OTf}]+{ }^{2,6-\mathrm{Cl}} \mathrm{PhNH}_{2}$ 
(7) $\mathrm{p} K_{\mathrm{d}}\left(\left[\mathrm{PhNH}_{3}\right][\mathrm{OTf}]\right)=-\Delta \mathrm{G}_{\mathrm{d}} /(2.303 \times \mathrm{RT})+\mathrm{p} K_{\mathrm{a}}(2,6-$ $\left.{ }^{\mathrm{Cl}} \mathrm{PhNH}_{3}^{+}\right)$

Calculations of the $\mathrm{p} K_{\mathrm{d}}$ of all of the relevant species (Table 1) shows that the $\mathrm{p} K_{\mathrm{d}}$ of $\left[\mathrm{Cp} *\left(\right.\right.$ exo $\left.\left.-\eta^{4}-\mathrm{C}_{5} \mathrm{Me}_{5} \mathrm{H}\right) \mathrm{Co}\right][\mathrm{OTf}]$ $\left(\mathrm{p} K_{\mathrm{d}}{ }^{\text {calc }}=11.8\right.$; Table 1$)$ falls within the range of the anilinium acids studied $\left(0.4 \leq \mathrm{p} K_{\mathrm{d}}{ }^{\text {calc }} \leq 15.7\right)$, suggesting there should be a significant acid dependence on the kinetics and thermodynamics of $\mathrm{Cp}_{2}{ }_{2} \mathrm{Co}$ protonation. To better elucidate the differences in $\mathrm{Cp}^{*}{ }_{2} \mathrm{Co}$ protonation between the acids studied, we investigated the kinetics of protonation for three acids, [ [2,6$\left.{ }^{\mathrm{Cl}} \mathrm{PhNH}_{3}\right]$ [OTf] (high selectivity; $\mathrm{p} K_{\mathrm{d}}{ }^{\text {calc }}=3.4$ ), ${ }^{[2,6-}$ $\left.{ }^{\mathrm{Me}} \mathrm{PhNH}_{3}\right][\mathrm{OTf}]$ (modest selectivity; $\mathrm{p}_{\mathrm{d}}^{\mathrm{calc}}=13.2$ ), and [ ${ }^{4-}$ $\left.{ }^{\text {OMe }} \mathrm{PhNH}_{3}\right][\mathrm{OTf}]$ (poor selectivity; $\mathrm{p} K_{\mathrm{d}}{ }^{\text {calc }}=15.8$ ).

Transition states for $\mathrm{Cp}^{*}{ }_{2}$ Co protonation were located for all three acids. To confirm that these transition states accurately reflect proton transfer, internal reaction coordinates (IRC) were followed to determine the reactant (IRC-A) and product (IRC-B) minima (Figure 2). These minima represent hydrogen bonded arrangements of the reactants and products. Protonation is found to have only a moderate barrier $\left(\Delta \mathrm{G}^{*}\right.$ in kcal $\left.\mathrm{mol}^{-1}\right)$ in all three cases: $\left(\left[{ }^{4-\mathrm{OMe}^{-}} \mathrm{PhNH}_{3}\right][\mathrm{OTf}],+4.5 ;\left[{ }^{2,6-}\right.\right.$ $\left.{ }^{\mathrm{Me}} \mathrm{PhNH}_{3}\right][\mathrm{OTf}],+3.8 ;$ [ $\left.\left.^{2,6-\mathrm{Cl}} \mathrm{PhNH}_{3}\right][\mathrm{OTf}],+1.3\right)$.

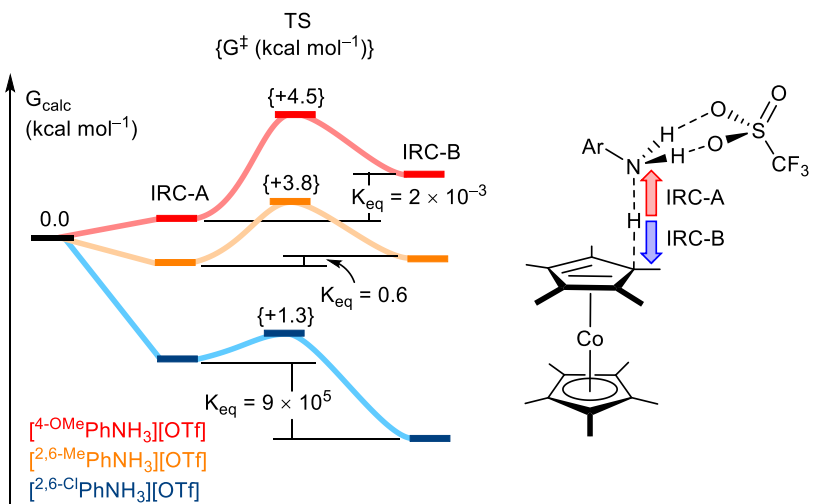

Figure 2. The kinetics and thermodynamics of protonation of $\mathrm{Cp}{ }_{2} \mathrm{Co}$ for three acids from different catalytic efficiency regimes

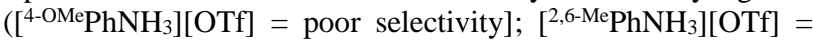

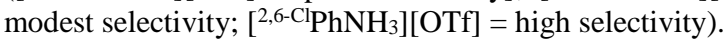

This suggests that $\mathrm{Cp}^{*}{ }_{2}$ Co protonation is kinetically accessible in all cases, in agreement with the experimental observation of background HER with each of these acids (see SI).

The small differences in rate, and the large variance in the equilibrium constant $K_{\text {eq }}$ defined in eq 8, points to a significant difference in the population of protonated metallocene, $\left[\mathrm{Cp} *\left(\right.\right.$ exo- $\left.\left.\eta^{4}-\mathrm{C}_{5} \mathrm{Me}_{5} \mathrm{H}\right) \mathrm{Co}\right][\mathrm{OTf}]$, for these anilinium acids during catalysis.

$$
K_{\mathrm{eq}}=\frac{\left[{ }^{\mathrm{R}} \mathrm{PhNH}_{2}-\mathrm{Cp}^{*}\left(e x o-\eta^{4}-\mathrm{C}_{5} \mathrm{Me}_{5} \mathrm{H}\right) \mathrm{Co}^{+}\right]}{\left[{ }^{\mathrm{P}} \mathrm{PhNH}_{3}^{+}-\mathrm{Cp}_{2}^{*} \mathrm{Co}\right]}
$$

We reason that the low solubility of the anilinium triflate acids, and the low catalyst concentration $\left(2.3 \mathrm{mM} \mathrm{P}{ }_{3}{ }^{\mathrm{B}} \mathrm{Fe}\right)$, leads to a scenario in which the interaction between the acid and the $\mathrm{Cp}_{2}{ }_{2} \mathrm{Co}$, the latter being present in excess relative to the iron catalyst (measured solubility of $\mathrm{Cp}^{*}{ }_{2} \mathrm{Co}$ at $-78^{\circ} \mathrm{C}$ in $\mathrm{Et}_{2} \mathrm{O}$ is $\sim 6 \mathrm{mM}$, see SI), significantly affects the overall kinetics of productive $\mathrm{N}-\mathrm{H}$ bond formation. As such, the difference in $\left[\mathrm{Cp}^{*}\left(\right.\right.$ exo $\left.\left.-\eta^{4}-\mathrm{C}_{5} \mathrm{Me}_{5} \mathrm{H}\right) \mathrm{Co}\right][\mathrm{OTf}]$ concentration and formation rate should relate to, and likely dominate, the origin of the observed $\mathrm{p} K_{\mathrm{a}}$ effect. This explanation, rather than one that involves differences in rates for the direct interaction of a given $\mathrm{P}_{3}{ }^{\mathrm{B}} \mathrm{FeN} \mathrm{N}_{\mathrm{x}} \mathrm{H}_{\mathrm{y}}$ species with an anilinium acid, better captures the collected data available. ${ }^{21}$

$\left[\mathrm{Cp}^{*}\left(\right.\right.$ exo- $\left.\left.\eta^{4}-\mathrm{C}_{5} \mathrm{Me} \mathrm{H}_{5} \mathrm{H}\right) \mathrm{Co}\right][\mathrm{OTf}]$, characterized by a very weak $\mathrm{C}-\mathrm{H}$ bond, should be a strong PCET donor, and we presume it serves such a role under the catalytic conditions being discussed herein. ${ }^{22}$ Its reactions with $\mathrm{P}_{3}{ }^{\mathrm{B}} \mathrm{FeN}_{\mathrm{x}} \mathrm{H}_{\mathrm{y}}$ intermediates may occur in a synchronous fashion, akin to HAT, or in an asynchronous fashion more akin to a PT-ET reaction. ${ }^{23}$ While many $\mathrm{P}_{3}{ }^{\mathrm{B}} \mathrm{FeN}_{\mathrm{x}} \mathrm{H}_{\mathrm{y}}$ intermediates may, at least in part, be generated via PCET with $\left[\mathrm{Cp} *\left(\right.\right.$ exo- $\eta^{4}-$ $\left.\left.\mathrm{C}_{5} \mathrm{Me}_{5} \mathrm{H}\right) \mathrm{Co}\right][\mathrm{OTf}],{ }^{24}$ available experimental data point to a critical role for such a reaction via trapping of the highly reactive first fixed intermediate, $\mathrm{P}_{3}{ }^{\mathrm{B}} \mathrm{FeNNH}$ (Figure 3), before it can bimolecularly release $\mathrm{H}_{2}$ (eq 3 ). We hence investigated this reaction in more detail.

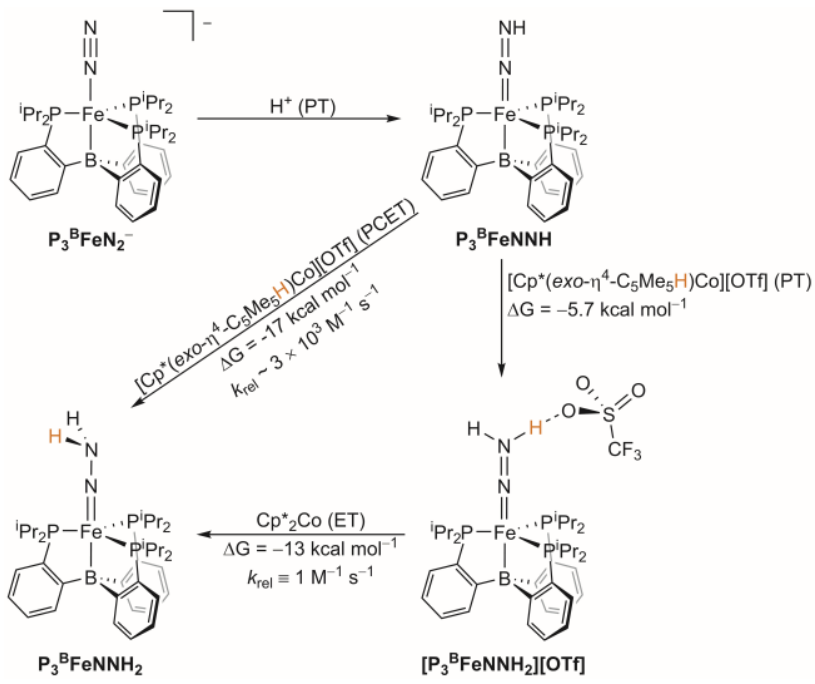

Figure 3. The calculated thermodynamics and kinetics of synchronous PCET and asynchronous PCET (PT-ET), between $\mathrm{P}_{3}{ }^{\mathrm{B}} \mathrm{FeNNH}$ and $\left[\mathrm{Cp} *\left(\right.\right.$ exo- $\left.\left.\eta^{4}-\mathrm{C}_{5} \mathrm{Me}_{5} \mathrm{H}\right) \mathrm{Co}\right][\mathrm{OTf}]$ to generate $\mathrm{P}_{3}{ }^{\mathrm{B}} \mathrm{FeNNH}_{2}$. Note: $k_{\text {rel }}$ for ET is defined as $1 \mathrm{M}^{-1} \mathrm{~s}^{-1}$.

Both a synchronous PCET $\left(\Delta \mathrm{G}_{\mathrm{PCET}}=-17.3 \mathrm{kcal} \mathrm{mol}^{-1}\right.$; eq 9) and an asynchronous PCET path $\left(\Delta \mathrm{G}_{\mathrm{PT}}=-5.7 \mathrm{kcal}\right.$ $\mathrm{mol}^{-1}, \Delta \mathrm{G}_{\mathrm{ET}}=-11.6 \mathrm{kcal} \mathrm{mol}^{-1}$; eq 10 and 11$)$, are predicted to be thermodynamically favorable.

$$
\begin{aligned}
& \text { (9) } \mathrm{P}_{3}{ }^{\mathrm{B}} \mathrm{FeNNH}+\left[\mathrm{Cp} *\left(\text { exo- } \eta^{4}-\mathrm{C}_{5} \mathrm{Me}_{5} \mathrm{H}\right) \mathrm{Co}\right][\mathrm{OTf}] \rightarrow \\
& \mathrm{P}_{3}{ }^{\mathrm{B}} \mathrm{FeNNH}_{2}+\left[\mathrm{Cp}^{*}{ }_{2} \mathrm{Co}\right][\mathrm{OTf}] \\
& \text { (10) } \mathrm{P}_{3}{ }^{\mathrm{B}} \mathrm{FeNNH}+\left[\mathrm{Cp}^{*}\left(\text { exo- } \eta^{4}-\mathrm{C}_{5} \mathrm{Me}_{5} \mathrm{H}\right) \mathrm{Co}\right][\mathrm{OTf}] \rightarrow \\
& {\left[\mathrm{P}_{3}{ }^{\mathrm{B}} \mathrm{FeNNH}_{2}\right][\mathrm{OTf}]+\mathrm{Cp}^{*}{ }_{2} \mathrm{Co}} \\
& \text { (11) }\left[\mathrm{P}_{3}{ }^{\mathrm{B}} \mathrm{FeNNH} \mathrm{H}_{2}\right][\mathrm{OTf}]+\mathrm{Cp}^{*}{ }_{2} \mathrm{Co} \rightarrow \\
& \mathrm{P}_{3}{ }^{\mathrm{B}} \mathrm{FeNNH} \mathrm{N}_{2}+\left[\mathrm{Cp}_{2}{ }_{2} \mathrm{Co}\right][\mathrm{OTf}]
\end{aligned}
$$

To evaluate the kinetics of these reactions the Marcus theory expressions ${ }^{25}$ and the Hammes-Schiffer method ${ }^{26}$ were used to approximate relative rates of bimolecular ET and PCET. We find that there is a slight kinetic preference for the fully synchronous PCET reaction $\left(k_{\mathrm{rel}}{ }^{\text {PCET }} \sim 3 \times 10^{3} \mathrm{M}^{-1} \mathrm{~s}^{-1}\right)$ compared to the fully asynchronous PT-ET reaction $\left(k_{\text {rel }}{ }^{\text {PT-ET }}\right.$ $\approx k_{\mathrm{rel}}^{\mathrm{ET}} \equiv 1 \mathrm{M}^{-1} \mathrm{~s}^{-1}$; Figure 3$){ }^{27}$

The above discussion leads to the conclusion that the efficiency for $\mathrm{NH}_{3}$ formation in this system is coupled to the kinetics and/or thermodynamics of the reaction between the anilinium triflate acid and the $\mathrm{Cp} *{ }_{2} \mathrm{Co}$ reductant. This conclusion is counterintuitive, as the protonation of $\mathrm{Cp}^{*}{ }_{2} \mathrm{Co}$ is also the requisite first step for background HER. ${ }^{28}$ The fact that a 
key HER intermediate can be intercepted and used for productive $\mathrm{N}_{2} \mathrm{RR}$ steps is an important design principle for such catalysis. Similar design strategies are currently being used to repurpose molecular cobalt HER catalysts for the reduction of unsaturated substrates. ${ }^{29}$

Efforts are often undertaken to suppress background reactivity between acid and reductant in catalytic $\mathrm{N}_{2} \mathrm{RR}$ systems. ${ }^{1 \mathrm{a}-\mathrm{b}} \mathrm{We}$ were hence particularly interested to explore whether the inclusion of a metallocene co-catalyst, in this case $\mathrm{Cp}{ }_{2} \mathrm{Co}$, might improve the yield, and/or the Faradaic efficiency (FE), for $\mathrm{N}_{2} \mathrm{RR}$ versus HER, in controlled potential electrolysis (CPE) experiments with $\mathrm{P}_{3}{ }^{\mathrm{B}} \mathrm{Fe}^{+}$under $\mathrm{N}_{2}$.

\section{Electrolysis studies.}

To set the context for this section of the present study, we had shown previously that $\sim 2.2$ equiv $\mathrm{NH}_{3}$ (per $\mathrm{Fe}$ ) could be generated via controlled potential electrolysis (CPE; $-2.3 \mathrm{~V}$ vs $\mathrm{Fc}^{+/ 0}$ ) at a reticulated vitreous carbon working electrode, using $\mathrm{P}_{3}{ }^{\mathrm{B}} \mathrm{Fe}^{+}$as the (pre)catalyst in the presence of $\mathrm{HBAr}_{4}{ }_{4}$ (50 equiv) at $-45^{\circ} \mathrm{C}$ under an atmosphere of $\mathrm{N}_{2}$. This yield of $\mathrm{NH}_{3}$ corresponded to $\mathrm{a} \sim 25 \% \mathrm{FE}$ which, while modest in terms of overall chemoselectivity, compares very favorably to FE's most typically reported for heterogeneous electrocatalysts for $\mathrm{N}_{2} \mathrm{RR}$ that operate below $100{ }^{\circ} \mathrm{C}(<2 \%)$. ${ }^{2,30}$

To further explore the possibility of using $\mathrm{P}_{3}{ }^{\mathrm{B}} \mathrm{Fe}^{+}$as an electrocatalyst for $\mathrm{N}_{2} \mathrm{RR}$, various conditions were surveyed to determine whether enhanced yields of $\mathrm{NH}_{3}$ could be obtained from CPE experiments. For example, various applied potentials were studied (ranging from -2.1 to $-3.0 \mathrm{~V} \mathrm{vs} \mathrm{Fc}^{+/ 0}$ ), the concentrations of $\mathrm{P}_{3}{ }^{\mathrm{B}} \mathrm{Fe}^{+}$and $\mathrm{HBAr}^{\mathrm{F}}{ }_{4}$ were varied, the ratio of acid to catalyst was varied, and the rate at which acid was delivered to the system was varied (e.g., initial full loadings, batch-wise additions, reloadings, or continuous slow additions). None of these studies led to substantial improvement in $\mathrm{N}_{2} \mathrm{RR}$; in all cases, $<2.5$ equiv of $\mathrm{NH}_{3}$ was obtained per $\mathrm{P}_{3}{ }^{\mathrm{B}} \mathrm{Fe}^{+}$. Attempts to vary the ratio of the electrode surface area to the working compartment solution volume, either by employing smaller cell geometries or by using different morphologies of glassy carbon as the working electrode (e.g., reticulated porous materials of different pore density or plates of different dimensions), also failed to provide substantial improvement in $\mathrm{NH}_{3}$ yield. The replacement of $\mathrm{HBAr}_{4}^{\mathrm{F}}$, the original acid used in our electrolysis studies, ${ }^{6 \mathrm{~d}}$ by 50 equiv of $\left[\mathrm{Ph}_{2} \mathrm{NH}_{2}\right][\mathrm{OTf}]$ led to similar yields of $\mathrm{NH}_{3}$ (Table 2, entry 1 ).

We next investigated the effect of $\mathrm{Cp}_{2} \mathrm{Co}^{+}$as an additive on the electrolysis/electrocatalysis. Traces of relevant cyclic voltammograms (Figure 4A and 4B) collected with glassy carbon as the working electrode in $\mathrm{Et}_{2} \mathrm{O}$ under glovebox atmosphere $\mathrm{N}_{2}$ at $-35{ }^{\circ} \mathrm{C}$ are provided. Background traces including only $\left[\mathrm{Ph}_{2} \mathrm{NH}_{2}\right][\mathrm{OTf}]$ are present in both panels (gray traces).
$\mathrm{Cp}_{2} \mathrm{Co}^{+}$(panel A, yellow trace), $\mathrm{Cp}_{2}{ }_{2} \mathrm{Co}^{+}$with the addition of ten equiv of $\left[\mathrm{Ph}_{2} \mathrm{NH}_{2}\right][\mathrm{OTf}]$ (panel $\mathrm{A}$, green trace), $\mathrm{P}_{3}{ }^{\mathrm{B}} \mathrm{Fe}^{+}$ (panel $\mathrm{B}$, dark blue trace), $\mathrm{P}_{3}{ }^{\mathrm{B}} \mathrm{Fe}^{+}$with the addition of ten equiv of $\left[\mathrm{Ph}_{2} \mathrm{NH}_{2}\right][\mathrm{OTf}]$ (panel $\mathrm{B}$, light blue trace), and $\mathrm{P}_{3}{ }^{\mathrm{B}} \mathrm{Fe}^{+}$ with the addition of one equiv of $\mathrm{Cp}_{2} \mathrm{Co}^{+}$and ten equiv of $\left[\mathrm{Ph}_{2} \mathrm{NH}_{2}\right][\mathrm{OTf}]$ (both panels, red trace).

Table 2. Yields and Faradaic Efficiencies of $\mathrm{NH}_{3}$ from CPE Experiments with $\mathrm{P}_{3}{ }^{\mathrm{B}} \mathrm{Fe}^{+}$

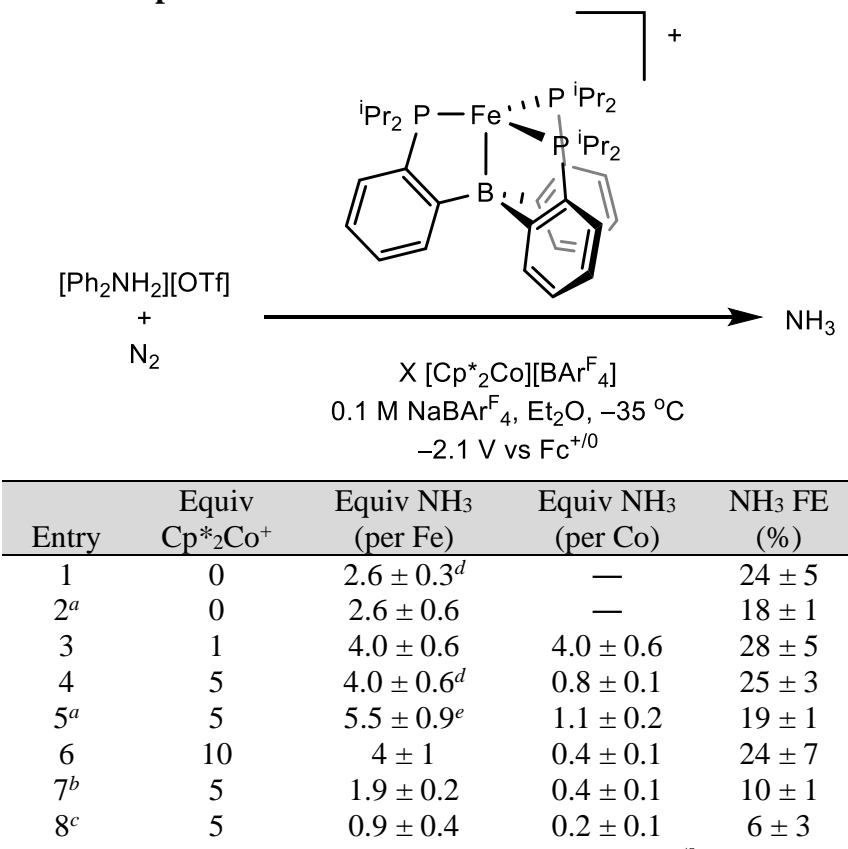

All CPE experiments conducted at $-2.1 \mathrm{~V}$ vs $\mathrm{Fc}^{+/ 0}$ with $0.1 \mathrm{M}$ $\mathrm{NaBAr}_{4}{ }_{4}$ in $\mathrm{Et}_{2} \mathrm{O}$ as solvent at $-35^{\circ} \mathrm{C}$ under an $\mathrm{N}_{2}$ atmosphere, featuring a glassy carbon plate working electrode, $\mathrm{Ag}^{+/ 0}$ reference couple isolated by a CoralPor ${ }^{\mathrm{TM}}$ frit referenced externally to $\mathrm{Fc}^{+/ 0}$, and a solid sodium auxiliary electrode. Working and auxiliary chambers separated by a sintered glass frit. See SI for further experimental details, controls, and additional data. Averages represent two runs unless noted. ${ }^{a}$ After initial electrolysis with 50 equiv $\left[\mathrm{Ph}_{2} \mathrm{NH}_{2}\right][\mathrm{OTf}]$, an additional 50 equiv $\left[\mathrm{Ph}_{2} \mathrm{NH}_{2}\right][\mathrm{OTf}]$ in $0.1 \mathrm{M} \mathrm{NaBAr}_{4} \mathrm{Et}_{2} \mathrm{O}$ solution was added to the working chamber, via syringe through a rubber septum, followed by additional CPE at $-2.1 \mathrm{~V} \mathrm{vs} \mathrm{Fc}^{+/ 0}$. The listed Equiv $\mathrm{NH}_{3}$ (per $\mathrm{Fe}$ ) for these runs is the total yield after both electrolysis experiments are completed. ${ }^{b}\left[{ }^{2,6-\mathrm{Cl}} \mathrm{PhNH}_{3}\right][\mathrm{OTf}]$ employed as the acid. ${ }^{c}\left[\mathrm{PhNH}_{3}\right][\mathrm{OTf}]$ employed as the acid. ${ }^{d}$ Average of three runs. ${ }^{e}$ Average of five runs.

The cyclic voltammogram of $\mathrm{Cp}^{*}{ }_{2} \mathrm{Co}^{+}$is shown in panel A (yellow trace), displaying the reversible $\mathrm{Cp}^{*} \mathrm{Co}^{+/ 0}$ couple at $-2.0 \mathrm{~V}$. The addition of $\left[\mathrm{Ph}_{2} \mathrm{NH}_{2}\right][\mathrm{OTf}]$ to $\mathrm{Cp}^{*}{ }_{2} \mathrm{Co}^{+}$causes an increase in current at this potential, consistent with HER 

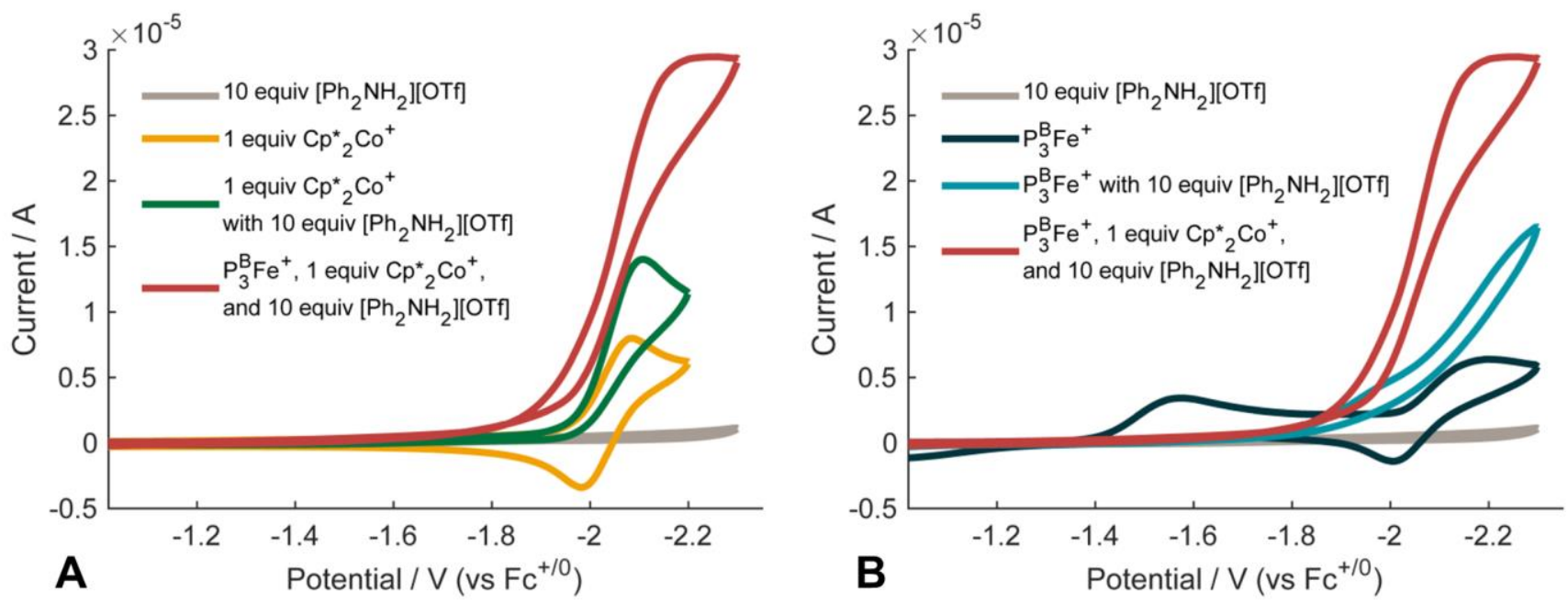

Figure 4. A) Cyclic voltammograms of 10 equiv $\left[\mathrm{Ph}_{2} \mathrm{NH}_{2}\right][\mathrm{OTf}]$ (gray trace), 1 equiv $\left[\mathrm{Cp}^{*}{ }_{2} \mathrm{Co}\right]\left[\mathrm{BAr}_{4}{ }_{4}\right]\left(\mathrm{Cp}_{2}{ }_{2} \mathrm{Co}^{+}\right.$) (yellow trace), 1 equiv $\mathrm{Cp}_{2} \mathrm{Co}^{+}$with 10 equiv $\left[\mathrm{Ph}_{2} \mathrm{NH}_{2}\right]\left[\mathrm{OTf}\right.$ (green trace), and $\mathrm{P}_{3}{ }^{\mathrm{B}} \mathrm{Fe}^{+}$with 1 equiv of $\mathrm{Cp}_{2}{ }_{2} \mathrm{Co}^{+}$and 10 equiv $\left[\mathrm{Ph}_{2} \mathrm{NH}_{2}\right][\mathrm{OTf}]$ (red trace). B) Cyclic voltammograms of 10 equiv $\left[\mathrm{Ph}_{2} \mathrm{NH}_{2}\right][\mathrm{OTf}]$ (gray trace), $\mathrm{P}_{3}{ }^{\mathrm{B}} \mathrm{Fe}^{+}$(dark blue trace), $\mathrm{P}_{3}{ }^{\mathrm{B}} \mathrm{Fe}^{+}$with 10 equiv $\left[\mathrm{Ph}_{2} \mathrm{NH}_{2}\right]$ [OTf] (light blue trace), and $\mathrm{P}_{3}{ }^{\mathrm{B}} \mathrm{Fe}^{+}$with 1 equiv of $\mathrm{Cp}^{*}{ }_{2} \mathrm{Co}^{+}$and 10 equiv $\left[\mathrm{Ph}_{2} \mathrm{NH}_{2}\right][\mathrm{OTf}]$ (red trace). All spectra are collected in $0.1 \mathrm{M} \mathrm{NaBAr}_{4}$ solution in Et $\mathrm{Et}_{2} \mathrm{O}$ at $-35{ }^{\circ} \mathrm{C}$ using a glassy carbon working electrode, and externally referenced to the $\mathrm{Fc}^{+/ 0}$ couple. Scan rate is $100 \mathrm{mV} / \mathrm{s}$.

catalyzed by $\mathrm{Cp}_{2} \mathrm{Co}^{+}$(panel $\mathbf{A}$, green trace).

Panel B provides the cyclic voltammogram of $\mathrm{P}_{3}{ }^{\mathrm{B}} \mathrm{Fe}^{+}$in the absence (dark blue trace, showing previously assigned and quasi-reversible $\mathrm{P}_{3}{ }^{\mathrm{B}} \mathrm{FeN}_{2}{ }^{0 /-}$ couple at $\sim-2.1 \mathrm{~V}$ ) and in the presence (light blue trace) of $\left[\mathrm{Ph}_{2} \mathrm{NH}_{2}\right][\mathrm{OTf}] .{ }^{31}$ The latter is indicative of modest HER and $\mathrm{N}_{2} \mathrm{RR}$. Also evident upon the addition of acid is the disappearance of a wave corresponding to the $\mathrm{P}_{3}{ }^{\mathrm{B}} \mathrm{Fe}^{+/ 0}$ couple at $\sim-1.6 \mathrm{~V}$. This wave, in the absence of acid, is broad and shows a large peak-to-peak separation, likely due to the presence of both $\mathrm{P}_{3}{ }^{\mathrm{B}} \mathrm{Fe}^{+}$and $\mathrm{P}_{3}{ }^{\mathrm{B}} \mathrm{FeN}_{2}{ }^{+}$in solution at $-35{ }^{\circ} \mathrm{C}$. The addition of a large excess of $\left[\mathrm{Ph}_{2} \mathrm{NH}_{2}\right][\mathrm{OTf}]$ presumably results in triflate binding (to generate $\mathrm{P}_{3}{ }^{\mathrm{B}} \mathrm{FeOTf}$, thereby attenuating the waves associated with the reduction of $\mathrm{P}_{3}{ }^{\mathrm{B}} \mathrm{Fe}^{+}$and $\mathrm{P}_{3}{ }^{\mathrm{B}} \mathrm{FeN}_{2}{ }^{+}$). The red trace of Panel A is reproduced in Panel B to illustrate the marked increase incurrent observed when $\mathrm{Cp}_{2}{ }_{2} \mathrm{Co}$ is added.

CPE studies were undertaken to characterize the reduction products associated with the red trace at $\sim-2.1 \mathrm{~V} \mathrm{vs} \mathrm{Fc}^{+/ 0}$. These studies employed a glassy carbon plate electrode, a $\mathrm{Ag}^{+/ 0}$ reference electrode that was isolated by a CoralPor ${ }^{\mathrm{TM}}$ frit and referenced externally $\mathrm{Fc}^{+/ 0}$ redox couple, and a solid sodium auxiliary electrode. The latter was used to avoid excessive, non-productive redox cycling between the working and auxiliary chambers. ${ }^{32}$ Unless otherwise noted, CPE experiments were performed at $-2.1 \mathrm{~V}$ versus $\mathrm{Fc}^{+/ 0}$, with $0.1 \mathrm{M}$ $\mathrm{NaBAr}_{4}^{\mathrm{F}}$ as the ether-soluble electrolyte, under a glovebox $\mathrm{N}_{2}$ atmosphere at $-35{ }^{\circ} \mathrm{C}$. The electrolysis was continued until the current had dropped to $1 \%$ of the initial current measured, or until 21.5 hours had passed. The Supporting Information provides additional details.

CPE experiments were conducted with the inclusion of 0 , 1,5 , and 10 equiv of $\mathrm{Cp}^{*}{ }_{2} \mathrm{Co}^{+}$with respect to $\mathrm{P}_{3}{ }^{\mathrm{B}} \mathrm{Fe}^{+}$, using excess $\left[\mathrm{Ph}_{2} \mathrm{NH}_{2}\right][\mathrm{OTf}]$ as the acid. In the absence of added $\mathrm{Cp}_{2} \mathrm{Co}^{+}$, a significant amount of $\mathrm{NH}_{3}$ was generated $(2.6 \pm$ 0.3 equiv per $\mathrm{Fe}$, entry 1 ), consistent with the previous finding that, in the presence of a strong acid, $\mathrm{P}_{3}{ }^{\mathrm{B}} \mathrm{Fe}^{+}$can electrolytically mediate $\mathrm{N}_{2}$-to- $\mathrm{NH}_{3}$ conversion. ${ }^{6 \mathrm{~d}}$ Notably, when a CPE experiment that did not include $\mathrm{Cp}_{2}{ }_{2} \mathrm{Co}^{+}$was reloaded with additional acid after electrolysis and electrolyzed again, the total yield of $\mathrm{NH}_{3}\left(2.6 \pm 0.6\right.$ equiv $\mathrm{NH}_{3}$ per $\mathrm{Fe}$, entry 2$)$ did not improve.
We found that inclusion of 1.0 equiv of $\mathrm{Cp}_{2} \mathrm{Co}^{+}$enhanced the $\mathrm{NH}_{3}$ yield, by a factor of $\sim 1.5$ (Table 2, entry 3 ) without decreasing the FE. The data provide a total yield, with respect to both $\mathrm{Fe}$ and $\mathrm{Co}$, that confirm modest, but still unequivocal, $\mathrm{N}_{2} \mathrm{RR}$ electrocatalysis. In single run experiments, the highest $\mathrm{NH}_{3}$ yield in the absence of $\mathrm{Cp}_{2}{ }_{2} \mathrm{Co}^{+}$was 2.8 equiv, compared with 4.4 equiv in the presence of 1 equiv of $\mathrm{Cp}_{2} \mathrm{Co}^{+}$. Conversely, the lowest single run $\mathrm{NH}_{3}$ yield in the absence of $\mathrm{Cp}^{*}{ }_{2} \mathrm{Co}^{+}$was 2.3 equiv, compared with 3.5 equiv in the presence of 1 equiv of $\mathrm{Cp}^{*}{ }_{2} \mathrm{Co}^{+}$.

Increasing the amount of added $\mathrm{Cp}_{2}{ }_{2} \mathrm{Co}^{+}$did not affect the $\mathrm{NH}_{3}$ yield (entry 4). However, the addition of a second loading of $\left[\mathrm{Ph}_{2} \mathrm{NH}_{2}\right][\mathrm{OTf}]$ following the first electrolysis (entry 5), followed by additional electrolysis, led to an improved yield of $\mathrm{NH}_{3}$, suggesting that some active catalyst is still present after the first run. ${ }^{6 \mathrm{~d}, 9}$ Even higher $\mathrm{Cp}^{*}{ }_{2} \mathrm{Co}^{+}$loading did not lead to higher $\mathrm{NH}_{3}$ yields (entry 6).

$\mathrm{CPE}$ of $\mathrm{P}_{3}{ }^{\mathrm{B}} \mathrm{Fe}^{+}$in the presence of $\mathrm{Cp}_{2}{ }_{2} \mathrm{Co}^{+}$was also explored with other acids. Replacing $\left[\mathrm{Ph}_{2} \mathrm{NH}_{2}\right][\mathrm{OTf}]$ in these experiments with [2,6-Cl $\left.\mathrm{PhNH}_{3}\right][\mathrm{OTf}]$ led to lower yields of $\mathrm{NH}_{3}$, and with $\left[\mathrm{PhNH}_{3}\right][\mathrm{OTf}]$ even lower yields of $\mathrm{NH}_{3}$ were observed (entries 7 and 8 respectively). The lower, but nonzero, yield of $\mathrm{NH}_{3}$ provided by $\left[\mathrm{PhNH}_{3}\right]$ [OTf] in these CPE experiments is consistent with chemical trials employing various acids (vide supra) and can be rationalized by the relative $\mathrm{p} K_{\mathrm{a}}$ of the acids (Table 1). The intermediate yield of $\mathrm{NH}_{3}$ provided by [ $\left.{ }^{2,6-\mathrm{Cl}} \mathrm{PhNH}_{3}\right][\mathrm{OTf}]$ in these $\mathrm{CPE}$ experiments is less consistent with simple $\mathrm{p} K_{\mathrm{a}}$ considerations, suggesting that additional factors are at play, perhaps including the relative stability of the acid or conjugate base to electrolysis.

To probe whether electrode-immobilized iron might contribute to the $\mathrm{N}_{2} \mathrm{RR}$ electrocatalysis, X-ray photoelectron spectroscopy (XPS) was used to study the electrode. After a standard CPE experiment with $\mathrm{P}_{3}{ }^{\mathrm{B}} \mathrm{Fe}^{+}, 5$ equiv of $\mathrm{Cp}^{*}{ }_{2} \mathrm{Co}^{+}$, and 50 equiv $\left[\mathrm{Ph}_{2} \mathrm{NH}_{2}\right][\mathrm{OTf}]$, the electrode was removed, washed with fresh $0.1 \mathrm{M} \mathrm{NaBAr}_{4}{ }_{4} \mathrm{Et}_{2} \mathrm{O}$ solution, then fresh $\mathrm{Et}_{2} \mathrm{O}$, and probed by XPS. A very low coverage of $\mathrm{Fe}(<0.3$ atom $\% \mathrm{Fe}$ ) was detected in the post-electrolysis material; no Fe was detected on a segment of the electrode which was not exposed to the electrolytic solution. This observation implies a detectable but likely small degree of degradation of $\mathrm{P}_{3}{ }^{\mathrm{B}} \mathrm{Fe}^{+}$ 
over the course of a 15 hour CPE experiment. Worth noting is that no Co was detected on the post-electrolysis electrode. This may be consistent with the known stability of metallocenes and the recently discovered stability of protonated-Cp* ligands on Rh. ${ }^{33}$

To test whether the small amount of deposited Fe material might be catalytically active for $\mathrm{N}_{2} \mathrm{RR}$, following a standard CPE experiment the electrode was removed from the cold electrolysis solution, washed with fresh $0.1 \mathrm{M} \mathrm{NaBAr}_{4} \mathrm{Et}_{2} \mathrm{O}$ at $-35{ }^{\circ} \mathrm{C}$ (the electrode itself was maintained at $-35^{\circ} \mathrm{C}$ at all times), and then used for an additional CPE experiment, under identical conditions except that $\mathrm{P}_{3}{ }^{\mathrm{B}} \mathrm{Fe}^{+}$was excluded. This CPE experiment yielded no detectable $\mathrm{NH}_{3}$. The charge passed, and $\mathrm{H}_{2}$ yield, were very similar to a "no $\mathrm{P}_{3}{ }^{\mathrm{B}} \mathrm{Fe}^{+ \text {" }}$ control experiment conducted with a freshly cleaned electrode (See SI for further details). Accordingly, a CPE experiment in the absence of $\mathrm{P}_{3}{ }^{\mathrm{B}} \mathrm{Fe}^{+}$demonstrated that $\mathrm{Cp}_{2}{ }_{2} \mathrm{Co}^{+}$serves as an effective electrocatalyst for HER with $\left[\mathrm{Ph}_{2} \mathrm{NH}_{2}\right][\mathrm{OTf}]$ as the acid source, but does not catalyze the $\mathrm{N}_{2} \mathrm{RR}$ reaction $(0 \% \mathrm{FE}$ for $\mathrm{NH}_{3}, 75 \% \mathrm{FE}$ for $\mathrm{H}_{2}$; see SI). This background HER, and the observed catalytic response to the addition of $\left[\mathrm{Ph}_{2} \mathrm{NH}_{2}\right][\mathrm{OTf}]$ at the $\mathrm{Cp}^{*}{ }_{2} \mathrm{Co}^{+/ 0}$ couple, provides circumstantial evidence for the formation of a protonated decamethylcobaltocene intermediate, $\mathrm{Cp} *\left(\eta^{4}-\mathrm{C}_{5} \mathrm{Me}_{5} \mathrm{H}\right) \mathrm{Co}^{+}$, on a timescale similar to that of the $\mathrm{N}_{2} \mathrm{RR}$ mediated by $\mathrm{P}_{3}{ }^{\mathrm{B}} \mathrm{Fe}^{+}$.

To probe whether the sodium auxiliary electrode used in the CPE experiments might play a non-innocent role as a chemical reductant, a standard CPE experiment with $\mathrm{P}_{3}{ }^{\mathrm{B}} \mathrm{Fe}^{+}$, 5 equiv $\mathrm{Cp}^{*} \mathrm{Co}^{+}$, and 50 equiv $\left[\mathrm{Ph}_{2} \mathrm{NH}_{2}\right]$ [OTf] was assembled, but was left to stir at $-35{ }^{\circ} \mathrm{C}$ for 43 hours without an applied potential bias. This experiment yielded 0.3 equiv $\mathrm{NH}_{3}$ (relative to $\mathrm{Fe}$ ), suggesting that background $\mathrm{N}_{2} \mathrm{RR}$ due to the sodium auxiliary electrode is very minor.

To ensure the $\mathrm{NH}_{3}$ produced was derived from the $\mathrm{N}_{2}$ atmosphere during these electrolysis experiments, as opposed to degradation of the anilinium acid used, a standard CPE experiment using $\mathrm{P}_{3}{ }^{\mathrm{B}} \mathrm{Fe}^{+}$, 5 equiv $\mathrm{Cp}_{2}{ }_{2} \mathrm{Co}^{+}$, and 50 equiv of $\left[\mathrm{Ph}_{2}{ }^{15} \mathrm{NH}_{2}\right][\mathrm{OTf}]$ was performed. Only ${ }^{14} \mathrm{NH}_{3}$ product was detected.

We also sought to compare the chemical $\mathrm{N}_{2} \mathrm{RR}$ catalysis efficiency of the $\mathrm{P}_{3}{ }^{\mathrm{B}} \mathrm{Fe}^{+}$catalyst under conditions similar to those used for electrocatalysis. Hence, chemical catalysis with $\mathrm{P}_{3}{ }^{\mathrm{B}} \mathrm{Fe}^{+}$, employing $\mathrm{Cp}{ }_{2} \mathrm{Co}$ as a reductant and $\left[\mathrm{Ph}_{2} \mathrm{NH}_{2}\right][\mathrm{OTf}]$ as the acid at $-35^{\circ} \mathrm{C}$ instead of the more typical temperature of $-78{ }^{\circ} \mathrm{C}$, in a $0.1 \mathrm{M} \mathrm{NaBAr}_{4} \mathrm{Et}_{2} \mathrm{O}$ solution, afforded lower yields of $\mathrm{NH}_{3}\left(1.8 \pm 0.7\right.$ equiv of $\mathrm{NH}_{3}$ per $\left.\mathrm{Fe}\right)$ than the yields observed via electrolysis with $\mathrm{Cp}_{2} \mathrm{Co}^{+}$as an additive. The lower yields of $\mathrm{NH}_{3}$ in these chemical trials, compared with our previously reported conditions $\left(12.8 \pm 0.5\right.$ equiv of $\mathrm{NH}_{3}$ per $\mathrm{Fe}$ at $\left.-78^{\circ} \mathrm{C}\right),{ }^{9}$ may be attributable to increased competitive HER resulting from a more solubilizing medium $(0.1 \mathrm{M}$ $\mathrm{NaBAr}_{4}{ }_{4} \mathrm{Et}_{2} \mathrm{O}$ vs pure $\left.\mathrm{Et}_{2} \mathrm{O}\right)$ and a higher temperature $(-35$ ${ }^{\circ} \mathrm{C}$ vs $\left.-78^{\circ} \mathrm{C}\right) .{ }^{9}$ These results suggest that an electrochemical approach to $\mathrm{NH}_{3}$ formation can improve performance, based on selectivity for $\mathrm{N}_{2} \mathrm{RR}$, of a molecular catalyst under comparable conditions.

\section{CONCLUSION}

Herein we described the first systematic $\mathrm{p} K_{\mathrm{a}}$ studies on a synthetic nitrogen fixation catalyst and find a strong correlation between $\mathrm{p} K_{\mathrm{a}}$ and $\mathrm{N}_{2} \mathrm{RR}$ vs HER efficiency. Chemical studies reveal that, on their own, the anilinium triflate acids employed in the catalysis are unable to generate the $\mathrm{N}-\mathrm{H}$ bonds of early-stage $\mathrm{N}_{2} \mathrm{RR}$ intermediates such as $\mathrm{P}_{3}{ }^{\mathrm{B}} \mathrm{FeNNH}{ }_{2}{ }^{+}$. We propose that the insolubility of these triflate acids prevents the sufficiently rapid proton transfer necessary to capture the critical but unstable first fixed intermediate, $\mathrm{P}_{3}{ }^{\mathrm{B}} \mathrm{FeNNH}$. Under catalytic conditions, we believe that the presence of the metallocene reductant $\left(\mathrm{Cp}^{*}{ }_{2} \mathrm{Co}\right)$ is essential, as this species can be protonated in situ to form $\mathrm{Cp} *\left(\eta^{4}-\right.$ $\left.\mathrm{C}_{5} \mathrm{Me}_{5} \mathrm{H}\right) \mathrm{Co}^{+}$, which in turn is effective in $\mathrm{N}-\mathrm{H}$ bond formation with early intermediates. This leads to the intriguing conclusion that an intermediate of the background HER pathway is redirected for productive $\mathrm{N}_{2} \mathrm{RR}$ chemistry during catalysis.

DFT studies illustrate that the $\mathrm{p} K_{\mathrm{a}}$ effect on the $\mathrm{N}_{2} \mathrm{RR}$ efficiency may be explained by the variation in the kinetics and thermodynamics of $\mathrm{Cp}{ }_{2}$ Co protonation by the different acids. Investigation of the reactivity of $\mathrm{Cp} *\left(\right.$ exo $\left.-\eta^{4}-\mathrm{C}_{5} \mathrm{Me}_{5} \mathrm{H}\right) \mathrm{Co}^{+}$ with the $\mathrm{P}_{3}{ }^{\mathrm{B}} \mathrm{FeNNH}$ intermediate revealed that PCET reactivity, either synchronous or asynchronous, is favorable and may proceed with only a small barrier, suggesting that $\mathrm{P}_{3}{ }^{\mathrm{B}} \mathrm{FeNNH}$ can be rapidly trapped by $\mathrm{Cp} *\left(\right.$ exo- $\left.\eta^{4}-\mathrm{C}_{5} \mathrm{Me}_{5} \mathrm{H}\right) \mathrm{Co}^{+}$. We suspect $\mathrm{Cp}^{*}\left(\eta^{4}-\mathrm{C}_{5} \mathrm{Me}_{5} \mathrm{H}\right) \mathrm{Co}^{+}$is likely involved in a variety of $\mathrm{N}-$ $\mathrm{H}$ bond forming reactions during the overall catalysis, including reactions with late-stage nitrogen fixation intermediates.

Despite the fact that $\mathrm{Cp}^{*}{ }_{2} \mathrm{Co}^{+}$itself catalyzes HER under the conditions employed for electrocatalytic $\mathrm{N}_{2} \mathrm{RR}$, we found that its inclusion in CPE experiments containing $\mathrm{P}_{3}{ }^{\mathrm{B}} \mathrm{Fe}^{+}$and acid under an $\mathrm{N}_{2}$ atmosphere led to modest improvements in the overall catalytic yield of $\mathrm{NH}_{3}$. This system represents what is to our knowledge the first unambiguous example of electrocatalytic $\mathrm{N}_{2} \mathrm{RR}$ mediated by a soluble, molecular coordination complex.

\section{ASSOCIATED CONTENT}

The Supporting Information is available free of charge via the Internet at http://pubs.acs.org.

Computational models (MOL)

Experimental procedures, characterization data (PDF)

\section{AUTHOR INFORMATION}

\author{
Corresponding Author \\ *jpeters@ caltech.edu
}

\section{ORCID}

Jonas C. Peters: 0000-0002-6610-4414

\section{Author Contributions}

The manuscript was written through contributions of all authors. All authors have given approval to the final version of the manuscript.

\$These authors contributed equally.

\section{ACKNOWLEDGMENTS}

This work was supported by the NIH (GM-075757) and the Resnick Sustainability Institute at Caltech. MJC, TJDC, and BDM are grateful for NSF Graduate Research Fellowships and MJC acknowledges a Caltech Environment Microbial Interactions (CEMI) Fellowship. This work made use of the Extreme Science and Engineering Discovery Environment (XSEDE), which is supported by the NSF Grant ACI-1053575. We also thank Pakpoom Buabthong for technical assistance with XPS measurements. 


\section{REFERENCES}

1 (a) Yandulov, D. V.; Schrock, R. R. Science 2003, 301, 76. (b) Arashiba, K.; Miyake, Y.; Nishibayashi, Y. Nat. Chem. 2011, 3, 120. (c) Anderson, J. S.; Rittle, J.; Peters, J. C. Nature 2013, 501, 84. (d) Imayoshi, R.; Tanaka, H.; Matsuo, Y.; Yuki, M.; Nakajima, K.; Yoshizawa, K.; Nishibayashi, Y. Angew. Chem. Int. Ed. 2015, 21, 8905. (e) Ung, G.; Peters, J. C. Angew. Chem. Int. Ed. 2015, 54, 532. (f) Kuriyama, S.; Arashiba, K.; Nakajima, K.; Matsuo, Y.; Tanaka, H.; Ishii, K.; Yoshizawa, K.; Nishibayashi, Y. Nat. Commun. 2016, 7, 12181. (g) Hill, P. J.; Doyle, L. R.; Crawford, A. D.; Myers, W. K.; Ashley, A. E. J. Am. Chem. Soc. 2016, 138, 13521. (h) Buscagan, T. M.; Oyala, P. H.; Peters, J. C. Angew. Chem. Int. Ed. 2017, 56, 6921. (i) Wickramasinghe, L. A.; Ogawa, T.; Schrock, R. R.; Müller, P. J. Am. Chem. Soc. 2017, 139, 9132. (j) Fajardo Jr., J.; Peters, J. C. J. Am. Chem. Soc. 2017, 139, 16105.

2 (a) Shipman, M. A.; Symes, M. D. Catal. Today 2017, 286, 57. (b) Kyriakou, V.; Garagounis, I.; Vasileiou, E.; Vourros, A.; Stoukides, M. Catal. Today 2017, 286, 2.

3 (a) McKone, J. R.; Marinescu, S. C.; Brunschwig, B. S.; Winkler, J. R.; Gray, H. B. Chem. Sci. 2014, 5, 865. (b) Bullock, R. M.; Appel, A. M.; Helm, M. L. Chem. Commun. 2014, 50, 3125.

${ }^{4}$ (a) Benson, E. E.; Kubiak, C. P.; Sathrum, A. J.; Smieja, J. M. Chem. Soc. Rev. 2009, 38, 89. (b) Appel, A. M.; Bercaw, J. E.; Bocarsly, A. B.; Dobbek, H.; DuBois, D. L.; Dupuis, M.; Ferry, J. G.; Fujita, E.; Hille, R.; Kenis, P. J. A.; Kerfeld, C. A.; Morris, R. H.; Peden, C. H. F.; Portis, A. R.; Ragsdale, S. W.; Rauchfuss, T. B.; Reek, J. N. H.; Seefeldt, L. C.; Thauer, R. K.; Waldrop, G. L. Chem. Rev. 2013, 113, 6621. (c) Francke, R.; Schille, B.; Roemelt, M. Chem. Rev. 2018, DOI: 10.1021/acs.chemrev.7b00459.

${ }^{5}$ Zhang, W.; Lai, W.; Cao, R. Chem. Rev. 2017, 117, 3717.

${ }^{6}$ (a) Pickett, C. J.; Talarmin, J. Nature 1985, 317, 652. (b) Al-Salih, T. I.; Pickett, C. J. J. Chem. Soc. Dalton Trans. 1985, 1255. (c) Pickett, C. J.; Ryder, K. S.; Talarmin, J. J. Chem. Soc. Dalton Trans. 1986, 1453. (d) Del Castillo, T. J.; Thompson, N. B.; Peters, J. C. J. Am. Chem. Soc. 2016, 138,5341 .

${ }^{7}$ In this context, a recent report in which the bioelectrosynthesis of ammonia by nitrogenase is coupled to $\mathrm{H}_{2}$ oxidation is also noteworthy: Milton, R. D.; Cai, R.; Abdellaoui, S.; Leech, D.; De Lacey, A. L.; Pita, M.; Minteer, S. D. Angew. Chem. Int. Ed. 2017, 56, 2680.

8 Very recently there was a report of electrolytic $\mathrm{NH}_{3}$ synthesis by $\mathrm{Cp}_{2} \mathrm{TiCl}_{2}$. Although rates and Faradaic efficiencies are discussed, no yields of $\mathrm{NH}_{3}$ are reported: Jeong, E.-Y.; Yoo, C.-Y.; Jung, C. H.; Park, J. H.; Park, Y. C.; Kim, J.-N.; Oh, S.-G.; Woo, Y.; Yoon, H. C. ACS Sustainable Chem. Eng. 2017, 5, 9662.

${ }^{9}$ Chalkley, M. J.; Del Castillo, T. J.; Matson, B. D.; Roddy, J. P.; Peters, J. C. ACS Cent. Sci. 2017, 3, 217.

${ }^{10}$ In some cases, the $\mathrm{p} K_{\mathrm{a}}$ of a particular anilinium acid was already known in THF in which case this value was used. In cases where the $\mathrm{p} K_{\mathrm{a}}$ has not been reported in THF a literature procedure was used to appropriately convert the $\mathrm{p} K_{\mathrm{a}}$ from the solvent in which it was measured into a value for THF. See SI for details.

${ }^{11}$ Consistent with this observation is that efforts to use other weak, nonanilinium acids such as benzylammonium triflate ( $\mathrm{p} K_{\mathrm{a}}$ in THF of 13.2) and collidinium triflate ( $\mathrm{p} K_{\mathrm{a}}$ in THF of 11.2) also led to no observed $\mathrm{NH}_{3}$ formation.

12 These results are also consistent with our previous observation of $\left[\mathrm{Ph}_{2} \mathrm{NH}_{2}\right][\mathrm{OTf}]\left(\mathrm{p} K_{\mathrm{a}}\right.$ in THF of 3.2) yielding $72 \pm 3 \% \mathrm{NH}_{3}$. See reference 9.

${ }^{13}$ Pham, D. N.; Burgess, B. K. Biochemistry 1993, 32, 13275.

${ }^{14}$ In some other reports on $\mathrm{N}_{2} \mathrm{RR}$ by molecular catalysts, efficiencies for $\mathrm{NH}_{3}$ have been reported for several acids, but typically these acids span only a small $\mathrm{p} K_{\mathrm{a}}$ range, electron yields are inconsistent, and variations are not explained. For a representative example, see Reference $1 \mathrm{~b}$.

${ }^{15}$ Anderson, J. S.; Cutsail III, G. E.; Rittle, J.; Connor, B. A.; Gunderson, W. A.; Zhang, L.; Hoffman, B. M.; Peters, J. C. J. Am. Chem. Soc. 2015, 137,7803 .

${ }^{16}$ Matson, B. D.; Peters, J. C. ACS Catal. 2018, 8, 1448.

${ }^{17}$ Recent results on a $\mathrm{Cr}-\mathrm{N}_{2}$ species also support the role of PCET in the formation of early-stage $\mathrm{N}_{2}$ fixation intermediates in the presence of collidinium triflate and a cobaltocene: Kendall, A. J.; Johnson, S. I.; Bullock, R. M.; Mock, M. T. J. Am. Chem. Soc. 2018, 140, 2528.
18 Grimme, S.; Antony, J.; Ehrlich, S.; Krieg, H. J. Chem. Phys. 2010, 132, 154104.

${ }^{19}$ (a) Tao, J.; Perdew, J. P.; Staroverov, V. N.; Scuseria, G. E. Phys. Rev. Lett. 2003, 91, 146401. (b) Weigend, F.; Ahlrichs, R. Phys. Chem. Chem. Phys. 2005, 7, 3297.

${ }^{20}$ For the $\mathrm{P}_{3}{ }^{\mathrm{B}} \mathrm{FeN} \mathrm{H}_{\mathrm{y}} \mathrm{H}_{\mathrm{y}}$ and related systems, this combination of functional and basis sets is able to reproduce not only crystallographic details, but also experimentally measured singlet-triplet gaps, reduction potentials, and $\mathrm{N}-\mathrm{H}$ BDFE's, as described in reference 16.

${ }^{21}$ In all cases where the basicity of $\mathrm{P}_{3}{ }^{\mathrm{B}} \mathrm{FeN}_{\mathrm{x}} \mathrm{H}_{\mathrm{y}}$ intermediates has been evaluated, they are predicted to be readily protonated by the anilinium triflate acids employed (see SI for details).

${ }^{22}$ DFT calculations suggest that almost all of the $\mathrm{P}_{3}{ }^{\mathrm{B}} \mathrm{FeN}_{\mathrm{x}} \mathrm{H}_{\mathrm{y}}$ intermediates on the $\mathrm{N}_{2} \mathrm{RR}$ pathway have $\mathrm{N}-\mathrm{H}$ bonds stronger than the $\mathrm{C}-\mathrm{H}$ bond in $\mathrm{Cp} *\left(\right.$ exo $\left.-\eta^{4}-\mathrm{C}_{5} \mathrm{Me}_{5} \mathrm{H}\right) \mathrm{Co}^{+}$, suggesting that, at least thermodynamically, the formation of these $\mathrm{N}-\mathrm{H}$ bonds by PCET is favorable. See reference 16.

${ }^{23}$ The reactivity of ring-functionalized $\mathrm{Cp}^{*}$ rings has been discussed previously in the context of electrocatalytic HER by $4 \mathrm{~d}$ and $5 \mathrm{~d}$ metals, but via a mechanism involving hydride transfer, rather than via PCET. See: (a) Pitman, C. L.; Finster, O. N. L.; Miller, A. J. M. Chem. Commun. 2016, 52, 9105. (b) Quintana, L. M. A.; Johnson, S. I.; Corona, S. L.; Villatoro, W.; Goddard, W. A.; Takase, M. K.; VanderVelde, D. G.; Winkler, J. R.; Gray, H. B.; Blakemore, J. D. Proc. Natl. Acad. Sci. 2016, 113, 6409. (c) Peng, Y.; Ramos-Garcés, M. V.; Lionetti, D.; Blakemore, J. D. Inorg. Chem. 2017, 56, 10824.

${ }^{24}$ Productive $\mathrm{N}-\mathrm{H}$ bond formation via PCET with models of late-stage $\mathrm{N}_{2}$ fixation intermediates (i.e., $\mathrm{M} \equiv \mathrm{N}$ or $\mathrm{M}-\mathrm{NH}_{2}$ ) has been observed previously: (a) Scepaniak, J. J.; Young, J. A.; Bontchev, R. P.; Smith, J. M. Angew. Chem. Int. Ed. 2009, 48, 3158. (b) Pappas, I.; Chirik, P. J. J. Am. Chem. Soc. 2015, 137, 3498. (c) MacLeod, K. C.; McWilliams, S. F.; Mercado, B. Q.; Holland, P. L. Chem. Sci. 2016, 7, 5736. (d) Lindley, B. M.; Bruch, Q. J.; White, P. S.; Hasanayn, F.; Miller, A. J. M. J. Am. Chem. Soc. 2017, 139, 5305.

${ }^{25}$ Marcus, R. A. J. Chem. Phys. 1956, 24, 966.

${ }^{26}$ Iordanova, N.; Decornez, H.; Hammes-Schiffer, S. J. Am. Chem. Soc. 2001, 123, 3723.

${ }^{27}$ We have assumed a PT-ET mechanism in which ET is rate limiting based on significantly lower reorganization energies and barriers for PT compared to ET. See SI for full description.

${ }^{28}$ Koelle, U.; Infelta, P. P.; Graetzel, M. Inorg. Chem. 1988, 27, 879.

${ }^{29}$ Call, A.; Casadevall, C.; Acuna-Pares, F.; Casitas, A.; Lloret-Fillol, J. Chem. Sci. 2017, 8, 4739.

${ }^{30}$ Very recently there has been a study of electrocatalytic $\mathrm{N}_{2} \mathrm{RR}$ under ambient conditions in ionic liquids with Fe nanoparticles that reports FE's for $\mathrm{NH}_{3}$ as high as 60\%: Zhou, F.; Azofra, L. M.; Ali, M.; Kar, M.; Simonov, A. N.; McDonnell-Worth, C.; Sun, C.; Zhang, X.; MacFarlane, D. R. Energy Environ. Sci. 2017, 10, 2516.

${ }^{31} \mathrm{We}$ believe that the quasi-reversible nature of the electrochemical couple results from a high reorganization energy; the $\mathrm{P}_{3}{ }^{\mathrm{B}} \mathrm{FeN}_{2}{ }^{0 /-}$ couple is fully reversible using chemical reagents: Moret, M.-E.; Peters, J. C. Angew. Chem. Int. Ed. 2011, 50, 2063.

${ }^{32}$ Due to the extensive diffusion between the working and auxiliary chambers, production of an oxidation product which can diffuse to the working electrode and be re-reduced at $-2.1 \mathrm{~V} \mathrm{vs} \mathrm{Fc}^{+/ 0}$ leads to excessive, nonproductive redox cycling between chambers over the course of the lengthy CPE experiments. Sodium metal as an electrode material provides a suitable solution to this technical challenge, as the product of its oxidation $\left(\mathrm{Na}^{+}\right)$is stable to the CPE conditions.

${ }^{33}$ Henke, W. C.; Lionetti, D.; Moore, W. N. G.; Hopkins J. A.; Day, V. W.; Blakemore, J.D. ChemSusChem. 2017, 10, 4589. 
TOC Graphic

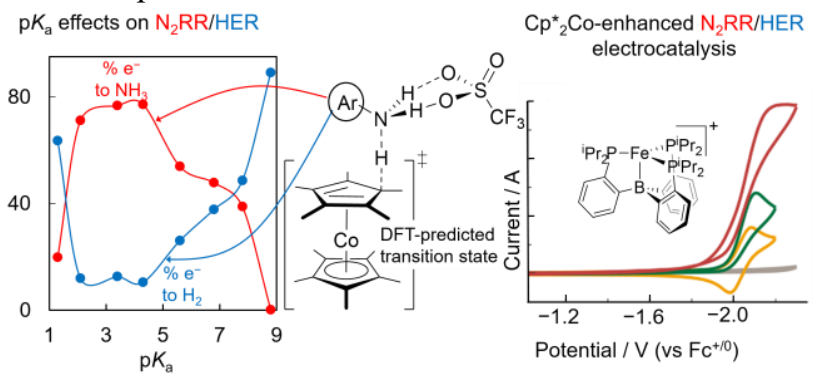

